\title{
ANALISA PENERAPAN PERHITUNGAN REKONSILIASI FISKAL TERHADAP LAPORAN KEUANGAN KOMERSIAL PT XYZ PADA WILAYAH KERJA KANTOR PELAYANAN PAJAK PULO GADUNG
}

\author{
Deddy Dariansyah \\ deddyjogjazz@yahoo.co.id \\ Universitas Indraprasta PGRI \\ Program Studi Pendidikan Ekonomi
}

\begin{abstract}
This research was conducted to determine the application of fiscal reconciliation calculations to commercial financial reports at PT XYZ, because there are differences in calculations, especially profit with commercial accounting and taxable profit (fiscal). To bridge the differences in commercial financial reports and more efficient fiscal financial reports, fiscal financial reports are prepared together with commercial financial reports, which means that even though commercial or business financial reports are prepared based on business accounting principles, taxation provisions are dominant in the reporting process. financial statements. This research method uses a Qualitative Descriptive approach, which describes making a fiscal reconciliation report on PT XYZ's commercial financial reports, as well as collecting a number of other supporting data to get a clear picture of the facts about the state of the 2019 Financial Statements at PT XYZ. The results of this study are the calculation of the Reconciliation Report in the framework of calculating the Corporate Income Tax from the tax profit / loss statement for December 31, 2019 with the net profit before tax based on the calculation in the December 31 commercial income statement obtained by PT amounting to Rp. After calculating the fiscal reconciliation of the commercial income statement, PT XYZ's net income before tax is $R p .10,315,000,000$.
\end{abstract}

Keywords : Fiscal Reconciliation, Commercial Financial Reports, Corporate Income Tax

\begin{abstract}
ABSTRAK
Penelitian ini dilaksanakan untuk mengetahui penerapan perthitungan rekonsilasi fiskal terhadap laporan keuangan komersial pada PT XYZ, karena adanya perbedaan perhitungan, terutama laba akuntansi komersial dengan laba kena pajak (fiskal). untuk menjembatani adanya perbedaan dalam laporan keuangan komersial dan laporan keuangan fiskal yang lebih efisien, maka Laporan Keuangan fiskal disusun bersama dengan laporan keuangan komersial, yang berarti bahwa meskipun laporan keuangan komersial atau bisnis disusun berdasarkan prinsip akuntansi bisnis, tetapi ketentuan perpajakan dominan dalam proses pelaporan penyusunan laporan keuangan. Metode penelitian ini menggunakan pendekatan Deskriptif Kualitatif, yaitu mendeskripsikan tentang membuat laporan rekonsiliasi fiskal atas laporan keuangan komersial PT XYZ, serta mengumpulkan sejumlah data data pendukung lainnya untuk mendapatkan gambaran fakta-fakta yang jelas tentang hal keadaan Laporan Keuangan Tahun 2019 pada PT XYZ tersebut. Hasil penelitian ini perhitungan Laporan Rekonsiliasi dalam rangka perhitungan Pajak Penghasilan Badan dari laporan Laba/Rugi fiskal untuk 31 Desember 2019 dengan Laba bersih sebelum pajak berdasarkan perhitungan dalam laporan laba-rugi komersial 31 Desember yang diperoleh PT sebesar Rp 11.317.000.000,-. setelah dilakukan perhitungan rekonsilasi fiskal atas laporan laba rugi komersial, laba bersih sebelum pajak menurut fiskal yang dimiliki PT XYZ adalah sebesar Rp. 10.315.000.000 .
\end{abstract}

Kata kunci: Rekonsiliasi Fiskal, Laporan Keuangan komersial Pajak penghasilan Badan 
PENDAHULUAN

Latar Belakang

Berdasarkan laporan Kementerian

Keuangan untuk Anggaran Pendapatan Belanja Negara (APBN) 2019, dari pemerintah menetapkan target penerimaan Pajak non- Migas adalah Rp. 1.786,4 trilyun, Dengan perluasan dasar perhitungan tersebut, pemerintah mengusulkan rasio penerimaan Pajak (Tax Ratio) dalam Rancangan Anggaran Pendapatan dan Belanja Negara Perubahan (APBN) 2019. Dengan semakin meningkatnya target penerimaan negara dari sektor pajak pada struktur APBN dari tahun ke tahun, yang besarnya rasio penerimaan sektor pajak terhadap total penerimaan dalam negeri berkisar $78 \%$ .untuk di tahun 2019 ini. Berikut ini Tabel Target Penerimaan Pajak selama 5 tahun dari Tahun 2015 sampai dengan 2019 dari Direktorat Jendral Pajak berdasarkan APBN adalah sebagai berikut:

\begin{tabular}{|l|l|l|}
\hline No & $\begin{array}{l}\text { Tahun } \\
\text { Penerimaan } \\
\text { Pajak }\end{array}$ & $\begin{array}{l}\text { Jumlah } \\
\text { Penerimaan }\end{array}$ \\
\hline 1 & 2015 & $\operatorname{Rp~1.294~triliun~}$ \\
\hline 2 & 2016 & $\operatorname{Rp~1.335.3~triliun~}$ \\
\hline 3 & 2017 & $\operatorname{Rp~1.339,6~triliun~}$ \\
\hline 4 & 2018 & $\operatorname{Rp~1.521,5~trilyun~}$ \\
\hline 5 & 2019 & $\operatorname{Rp~1.786,4~trilyun~}$ \\
\hline
\end{tabular}

\section{Sumber Direktorat Jendral Pajak}

Dari tabel di atas terlihat sangat jelas bahwa setiap tahunnya target penerimaan meningkat jumlah nya, berdasarkan Anggaran Pendapatan Belanja Negara (APBN) Tahun 2019. Hal ini diperlukan langkah-langkah strategis dan tepat oleh Direktorat Jendral Pajak sebagai institusi pengumpul penerimaan negara di Indonesia, agar rencana penerimaan pajak dapat tercapai, dari Pihak Direktorat Jendral Pajak menjalankan Program Ekstensifikasi dan Intensikasi, Untuk ini diperlukan peran aktif dari masyarakat beperan serta dalam membayar pajak untuk membiayai pembangunan di Indonesia. sistem pemungutan pajak yang berlaku saat ini adalah Self Assessment System. Tujuan diberlakukannya sistem ini agar masyarakatmemiliki kesadaran untuk memenuhi kewajiban di bidang perpajakannya.Oleh karena itu wajib pajak harus mengetahui segala hak dan kewajibannyadengan baik dan benar seperti, bagaimana cara menghitung, melaporkan serta menyetorkan pajakterutangnya, bagaimana mengajukan keberatan dan banding, bagaimanamengajukan restitusi (pengembalian) pajak, dan lain-lain. Dalam hal ini penulis sangat tertarik akan membahas serta ingin meneliti analisa penerapan perhitungan rekonsilasi fiskal terhadap laporan keuangan PT XYZ, dikarenakan perusahaan ini berada di wilayah kerja Kantor Pelayanan Pratama Pulo Gadung. Penulis mengadakan penelitian ini selama lebih dari 3 bulan pada PT XYZ ini. Setiap Perusahaan di Indonesia saat ini telah memiliki Laporan Keuangan setiap tahunnya yang bertujuan untuk mengetahui kinerja suatu perusahaan, selain itu juga Laporan Keuangan perusahaan tersebut dipergunakan juga untuk melapor dan membuat perhitungan dalam membayar pajaknya. Rekonsiliasi Fiskal dalam laporan keuangan perusahaan yang dibuat oleh Perusahaan (Wajib Pajak) terjadi karena adanya perbedaan perhitungan, khususnya laba menurut akutansi (komersial), dengan perhitungan laba menurut Perpajakan (fiskal). Laporan Keuangan disusun berdasarkan berdasarkan prinsip yang berlaku umum, yaitu Standar Akutansi Keuangan (SAK), sedangkan untuk kepentingan fiskal, Laporan Keuangan disusun berdasarkan Peraturan Perpajakan(Undang Undang Pajak Penghasilan). Untuk mengatasi perbedaan tersebut digunakan beberapa pendekatan dalam penyusunan laporan keuangan fiskal, yaitu:

Laporan Keuangan fiskal disusun secara beriringan dengan laporan keuangan komersial, artinya meskipun laporan keuangan komersial atau bisnis disusun berdasarkan prinsip akutansi bisnis, tetapi ketentuan perpajakan sangat dominan dalam mendasari proses penyusunan laporan keuangan.

Laporan keuangan fiskal disusun dengan menyisipkan ketentuan ketentuan pajak dalam laporan keuangan bisnis, artinya pembukuan yang diselenggarakan perusahaan didasarkan perusahaan didasarkan pada prinsip akutansi bisnis, tetapi jika ada ketentuan perpajakan yang tidak sesuai dengan prisnip akautansi bisnis maka diprioritaskan adalah ketentuan Perpajakan.

Untuk menjembatani adanya perbedaan dalam laporan keuangan komersial 
dan laporan keuangan fiskal agar lebih efesiensi maka Laporan Keuangan fiskal disusun secara beriringan dengan laporan keuangan komersial, artinya meskipun laporan keuangan komersial atau bisnis disusun berdasarkan prinsip akutansi bisnis, tetapi ketentuan perpajakan sangat dominan dalam mendasari proses penyusunan laporan keuangan. Penyebab perbedaan laporan keuangan komersial dan laporan keuangan fiskal adalah karena terdapat perbedaan prinsip akutansi, metode dan prosedur akutansi, perbedaan pengakuan penghasilan dan biaya, serta perbedaan perlakuan penghasilan dan biaya. Dalam menyikapi perbedaan-perbedaan yang terjadi antara Laporan Keuangan Laba Rugi Komersial dan Laba Rugi Fiskal, berdasarkan Standar Akuntansi Keuangan dan serta Undang-Undang perpajakan yang berlaku, atas dasar ini telah dilakukan penelitian jurnal sebelumnyaberdasarkan teori yang ada dan peraturan dari Direktorat Jendral Pajak, dengan judul analisis penerapan laporan rekonsiliasi fiskal terhadap laporan keuangan komersial pada PT Citra Karya Sejati, (Irene Maria dan Siti Khairani, 2011) serta penerapan laporan keuangan terhadap laporan rekonsiliasi fiskal terhadap PT XYZ.

\section{Permasalahan}

Berdasarkan permasalahan pada latar belakang, maka rumusan masalah yang akan diteliti pada penelitian ini adalah:

1. Untuk mengetahui perbedaan perhtiungan laporan keuangan komersial dan laporan keuangan fiskal

2. Bagaimana PT XYZ menerapkan perhitungan koreksi fiskal atas laporan keuangan komersial tahun 2019 dikarenakan adanya perbedaan biaya biaya sesuai dengan undang undang perpajakan

\section{Tujuan}

Tujuan dari penelitian ini adalah untuk mengetahui apakah PT XYZ sudah menerapkan perhitungan rekonsiliasi fiskal terhadap Laporan Keuangan Komersial perusahaan sesuai dengan undang undang perpajakan.

\section{TINJAUAN PUSTAKA}

Sebelum membahas pengertian Rekonsiliasi Fiskal, terlebih dahulu penulis akan menjelaskan pengertian Pajak berdasarkanUndang Undang Nomor 16 tahun
2009 tentang perubahan tentang Ketentuan Umum dan Tata cara Perpajakan, Wajib Pajak adalah kontribusi wajib kepada negara yang terutang oleh pribadi atau badan yang bersifat memaksa berdasarkan Undang Undang, dengan tidak mendapatkan imbalan secara langsung dan digunakan untuk keperluan negara bagi sebesar besarnya untuk kemakmuran rakyat.

Sedangkan Wajib Pajakmenurut Soemitro dalam Mardiasmo (2019) adalah iuran rakyat kepada kas negara berdasarkan undang undang (yang didapat dipaksakan) dengan tiada mendapatkan jasa timbale (kontraprestasi) yang langsung dapat ditunjukkan dan yang digunakan membayar pengeluaran umum. Berdasarkan Undang Undang Nomor 36 Tahun 2008 Wajib Pajak dibagi menjadi dua, Wajib Pajak Orang Pribadi adalah orang pribadi yang mendapatkan atau menerima penghasilan dari kegiatan usaha yang dilakukan, sedangkan Wajib Pajak Badan adalah sekumpulan orang atau modal yang merupakan kesatuan yang mendapatkan atau menerima penghasilan dari kegiatan usaha yang dilakukan, meliputi PT, CV, Firma, BUMN, BUMD, Kongsi, Koperasi, Dana Pensiun, Yayasan dll

Rekonsiliasi Fiskal menurut Supriyanto (2016) adalah suatu proses penyesuaian laporan Laba/ rugi fiskal berdasarkan ketentuan perundang undangan Perpajakan yang belaku yang harus dilakukan oleh wajib pajak sebelum menghitung Pajak Penghasilan (PPh) bagi wajib pajak badan dan wajib pajak orang pribadi (yang menggunakan pembukuan dalam menghitung penghasilan kena pajak). Rekonsiliasi Fiskal yang dilakukan oleh Wajib Pajak karena terdapat perbedaan perhitungan, khususnya laba menurut Akutansi (Komersial) dengan laba menurut Pajak (Fiskal). Untuk kepentingan komersial atau bisnis laporan keuangan disusun berdasarkan Standar Akutansi Keuangan (SAK), sedangkan laporan Rekonsiliasi Fiskal disusun berdasarkan peraturan pajak yang berlaku Undang Undang Pajak Penghasilan. Perbedaan kedua dasar dalam penyusunan laporan keuangan tersebut mengakibatkan perbedaan perhitungan laba (rugi) suatu 
entitas pajak. menurut Siti Resmi (2018) Rekonsiliasi fiskal terjadi karena adanya perbedaan perlakuan / pengakuan penghasilan maupun biaya antara akuntansi komersial dengan akuntansi pajak.

Sedangkan menurut Pohan (2014) laporan keuangan (komersial) adalah menyediakan informasi yang menyangkut posisi keuangan, kinerja, serta perubahan posisi keuangan suatu perusahaan yang sangat bermanfaat bagi sejumlah besar pengguna dalam pengambilan keputusan ekonomi.laporan keuangan menyajikan informasi mengenai entitas yang meliputi aset, liabilitas, ekuitas, pendapatan, dan beban termasuk keuntungan dan kerugian, kontribusi dari dan distribusi kepada pemilik dalam kapasitasnya sebagai pemilik dan arus kas. Informasi tersebut beserta informasi lain yang terdapat pada catatan atas laporan keuangan, membantu pengguna laporan keuangan dalam memprediksi arus kas masa depan dan khususnya dalam hal waktu dan kepastian diperolehnya kas dan setara kas.

Penyebab perbedaan Laporan Keuangan komerisal dengan Laporan Keuangan Fiskal adalah terdapat perbedaan prinsip akutansi, perbedaan pengakuan penghasilan dan biaya, antara lain:

Perbedaan metode Penilaian persediaan metode perhitungan / penentuan harga perolehan persediaan seperti rata rata (average), masuk pertama keluar pertama (FIFO), masuk terakhir keluar pertama (LIFO). Dalam perhitungan Fiskal hanya membolehkan memilih dua metode: rata rata (average), masuk pertama keluar pertama (FIFO).

\section{Metode Penyusutan dan}

amortisasi, dalam akutansi komersial membolehkan memilih metode penyusutan seperti metode garis lurus (Straight Line Method), metode saldo menurun( Declining Balanced Method), metode jumlah angka tahun (sum of the years digits method), metode jam jasa, metode jam jumlah unit produksi. Dalam perhitungan Fiskal hanya membolehkan memilih dua metode garis lurus (Straight Line Method) untuk perhitungan harta berwujud bangunan, metode saldo menurun( Declining Balanced Method) untuk perhitungan kelompok harta berwujud jenis non bangunan. Sedangkan besarnya penyusutan pada Akutansi Komersial manajemen dapat menaksir sendiri umur ekonomis atau masa manfaat suatu asset. Sedangkan menurut Fiskal umur ekonomis atau masa manfaat diatur atau ditetapkan berdasarkan keputusan Menteri Keuangan antara lain:

\section{Metode Penghapusan Piutang ,}

dalam Akutansi Komersial penghapusan Piutang ditentukan berdasarkan metode cadangan. Sedangkan dalam menurut Fiskal penghapusan piutang dilakukan pada saat piutang nyata nyata tidak dapat ditagih dengan syrat syarat tertentu yag diatur dalam peraturan perpajakan. Pembentukan cadangan Fiskal hanya diperolehkan untuk Industri tertentu seperti Usaha Bank, sewa guna usaha dengan hak opsi, usaha asuransi, usaha pertambangan yang dibatasi dengan Peraturam Perpajakan.

Perbedaan penghasilan dan biaya / pengeluaran menurut akutansi dan menurut fiskal dapat dikelompokkan menjadi perbedaan tetap (permanent differences) dan perbedaan sementara atau waktu (timing differences). Perbedaan tetap terjadi karena transaksi transaksi pendapatan dan biaya diakui menurut akutansi komersial tetapi tidak diakui menurut fiskal. Perbedaan tetap mengakibatkan laba (rugi) bersih menurut akutansi berbeda (secara tetap) dengan penghasilan (aba) kena pajak menurut fiskal. contoh perbedaan tetap adalah:

Penghasilan yang pajaknya bersifat final, seperti bunga Bank, deviden, sewa tanah dan bangunan, dan penghasilan lain sebagaimana diatur dalam undang undang pajak penghasilan Tahun 2008 pasal 4 ayat 2

Penghasilan yang tidak termasuk Objek Pajak seperti Deviden yang diterima oleh Perseroan Terbatas, Koperasi, BUMN / BUMD, bunga yang diterima oleh Perusahaan reksa dana, dan penghasilan lain sebagaimana diatur dalam pasal 4 ayat 3 Undang Undang Pajak Penghasilan Tahun 2008.

Biaya / Pengeluaran yang tidak diperbolehkan sebagai penghasilan bruto 
seperti pembayaran imbalan dalam bentuk natura, sumbangan, biaya/ pengeluaran untuk kepentingan pribadi pemilik, cadangan atau pemupukan dana cadangan, pajak penghasilan dan biaya atau pengurang lain yang tidak diperbolehkan (nondeductible expenses) menurut fiskal sesuai pasal 9 ayat 1 Undang Undang Pajak Penghasilan.

Perbedaan waktu (timing differences)

terjadi karena perbedaan waktu pengakuan pendapatan dan biaya dalam menghitung laba. Suatu biaya atau penghasilan diakui menurut akutansi komersial belum diakui menurut fiskal. Perbedaan ini bersifat sementara karena akan tutup pada periode sesudahnya. Contoh perbedaan ini antara lain: Pengakuan Piutang tak tertagih, penyusutan harta berwujud, amortisasi harta tak berwujud, penilaian dan lain lain. Untuk memperjelas pembahasan ini diambil satu contoh, yaitu penyusutan harta berwujud yag mengakibatkan perbedaan bersifat sementara( waktu). Suatu harta berwujud mempunyai harga perolehan $\mathrm{Rp}$ 500.000.000,-, menurut ketentuan fiskal harta berwujud tersebut termasuk non bangunan kelompok I ( masa manfaat 4 tahun), sedangkan menurut akutansi komersial ditaksir mempunyai umur ekonomis 5 tahun. Menurut akutansi komersial, besarnya penyusutan setiap tahun adalah $\mathrm{Rp}$ 100.000.000,-, sedangkan menurut fiskal adalah sebesar Rp 125.000.000,- perbedaan penyusutan ini mengakibatkan laba tahun pertama sampai dengan tahun keempat lebih tinggi Rp 25.000.000,- dibandingkan akutansi komersial. Pada akhir tahun kelima menurut fiskal tidak ada biaya penyusutan.

Di dalam Laporan Rekonsiliasi Fiskal adanya perbedaan sebagai Koreksi fiskal positif dan Koreksi fiskal negatif yaitu pengeluaran/ beban / biaya dalam perpajakan (fiskal) tidak sepenuhnya sama dengan menurut akutansi komersial. Sesuai dengan Undang Undang Pajak Penghasilan No 36 Tahun 2008, pengeluaran / beban/ biaya dibedakan menjadi dua yaitu:

$$
\text { Sesuai Pasal } 6 \text { Ayat } 1
$$

Pengeluaran/beban/biaya yang dapat dikurangkan dari penghasilan bruto (deductible expenses) dimasukan kategori Koreksi Fiskal positif, adalah pengeluaran/ beban / biaya yang mempunyai hubungan langsung dengan usaha atau kegiatan untuk mendpatkan, menagih dan memelihara penghasilan yang merupakan Objek Pajak yang pembebananya dapat dilakukan dalam pengeluaran atau masa masa manfaat atas pengeluaran tersebut. Biaya biaya secara langsung atau tidak langsung berkaitan dengan kegiatan usaha antara lain: biaya pembelian bahan baku, yang berhubungan dengan pekerjaan : Gaji, bonus, honorarium, bonus gratifikasi, tunjangan dan lain lain. bunga, biaya sewa, royalty, biaya perjalanan, biaya pengolahan limbah, premi asuransi dan lain lain

Sesuai Pasal 9 ayat 1 pengeluaran/beban/biaya yang tidak dapat dibebankan sebagai biaya (nondeductible expenses) dimasukan kategori pada Koreksi Fiskal Negatif, adalah pengeluaran/beban/biaya yang mempunyai hubungan langsung dengan usaha atau kegiatan untuk mendapatkan, menagih dan memelihara penghasilan yang bukan merupakan Objek Pajak atau pengeluaran dilakukan tidak dalam batas batas yang wajar yang dipengaruhi oleh hubungan istimewa tidak boleh dikurangkan dari penghasilan bruto. Sesuai dengan pasal 9 ayat 1 contohnya sebagai berikut:

- biaya yang dibebankan atau dikeluarkan untuk kepentingan pribadi pemegang saham, sekutu, atau anggota

- pembagian laba dengan nama dan bentuk apapun seperti : Deviden, termasuk deviden yang dibayarkan oleh perusahaan asuransi kepada pemegang polis dan pembagian SHU koperasi dan lain lain,

- pembentukan atau penumpukan dana cadangan

- $\quad$ sanksi administrasi berupa bunga, denda dan kenaikan serta sanksi denda yang berkenann dengan perundang undangan di bidang perpajakan dan lain lain.

Perbedaan Koreksi Fiskal Positif apabila yaitu:

- Pendapatan menurut Fiskal lebih besar dari pada Akutansi Komersial, tetapi tidak diakui menurut Akutansi Komersial

- Biaya /pengeluaran menurut Fiskal lebih kecil dari pada Akutansi Komersial, tetapi tidak diakui menurut Akutansi Komersial.

- Perbedaan Koreksi Fiskal Negatif apabila yaitu:

- Pendapatan menurut Fiskal lebih kecil dari pada menurut Akutansi Komersial tidak diakui menurut fiskal ( bukan objek pajak) tetapi diakui menurut Akutansi Komersial 
- Biaya/ Pengeluaran menurut Fiskal lebih besar dari pada menurut Akutansi Komersial, diakui di Fiskal tetapi tidak diakui oleh Akutansi Komersial.

- Suatu pendapatan telah dikenakan Pajak Penghasilan bersifat Final

\section{Berikut ini Siklus Latar Belakang Rekonsiliasi Fiskal}

Perbedaan antara laba (rugi) komersial dengan fiskalWajib pajak tidak perlu membuat pembukuan ganda, melainkan cukup pada waktu mengisi SPT Tahunan PPh terlebih dahulu harus dilakukan koreksi-koreksi fiskal dilakukan baik terhadap penghasilan maupun terhadap biaya-biaya (pengurang penghasilan bruto).

Siklus Rekonsiliasi Fiskal dengan pendekatan L/R adalah sebagai berikut:

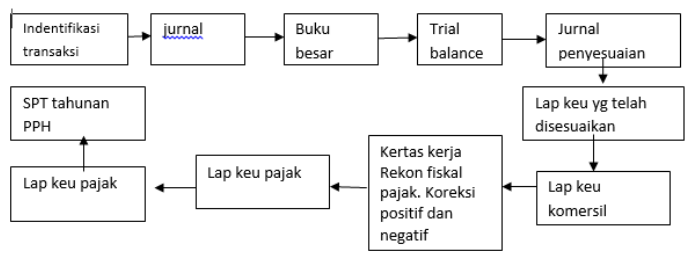

\section{METODE PENELITIAN}

Metode penelitian ini menggunakan pendekatan Deskriptif Kualitatif, dalam penelitian ini bersifat Deskriptif Kualitiatif yaitu mendeskripsikan tentang membuat laporan rekonsiliasi fiskal atas laporan keuangan komersial PT XYZ, serta mengumpulkan sejumlah data data pendukung lainnya untuk mendapatkan gambaran fakta-fakta yang jelas tentang hal keadaan Laporan Keuangan Tahun 2019 pada PT XYZ tersebut. Pengertian Metode deskriptif Sugiyono (2016) adalah Metode deskriptif adalah metode yang digunakan untuk menggambarkan atau menganalisis suatu hasil penelitian tetapi tidak digunakan untuk membuat kesimpulan yang lebih luas. Sedangkan menurut Sugiyono (2016) Metode penelitian kuantitatif dapat diartikan sebagai metode penelitian yang berlandaskan pada filsafat positivisme, digunakan untuk meneliti pada populasi atau sampel tertentu. Teknik pengambilan sampel pada umumnya dilakukan secara random, pengumpulan data menggunakan instrumen penelitian, analisis data bersifat kuantitatif/statistik dengan tujuan untuk menguji hipotesis yang telah ditetapkan.

Metode Pengumpulan Datayaitu pengumpulan data dilakukan untuk memperoleh informasi yang dibutuhkan dalam rangka mencapai tujuan.Dalam proses pengumpulan data yang diperlukan, penulis menggunakan 2(dua) teknik pengumpulan data yaitu;

Interview, yaitu mengadakan wawancara dalam hal ini tanya jawab mekanisme membuat laporan keuangan perusahaan setiap bulan dan tahunnya serta laporan rekonsiliasi fiskal pajak, serta tata cara pelaporan pajak perusahaan, dengan seorang Manajer Keuangan dan dua Staf keuanganPT XYZ yang berhubungan dengan penelitian ini

Berupa dokumen dokumen yang ada seperti laporan Keuangan perusahaan, laporan rekonsiliasi fiskal pajak perusahaan serta dokumen yang lainnya yang berkaitan dengan penelitian ini

Metode Analisis Kualitatif yang digunakan penulis dalam menyelesaikan permasalahan dalam penelitian ini adalah proses analisis merupakan proses awal dalam tahap perencanaanpenyelesaian suatu masalah, di dalam penelitian ini, penulis akan mempelajari dari awal cara membuat Laporan Keuangan perusahaan berdasarkan transaksi transaksi yang ada setiap bulan dan tahunnya yang ada pada PT XYZ dan proses membuat Laporan rekonsiliasi fiskal pajak, setelah itu diteliti dan analisa apakah laporan keuangan perusahaan dan Laporan Rekonsiliasi Fiskal pada PT XYZ yang dibuattersebut sudah benar benar dan telah sesuai dengan peraturan Pajak yang berlaku di Indonesiasaat ini.

\section{HASIL DAN PEMBAHASAN}

Dalam penelitian dan pembahasan ini Rekonsiliasi fiskal dilakukan berdasarkan dari laporan laba rugi komersial yang disusun oleh Wajib Pajak. Laba (rugi) komersial tersebut dilakukan koreksi fiskal sehingga 
menghasilkan laba (rugi) fiskal atau sering disebut penghasilan neto fiskal. Dalam melakukan koreksi fiskal yang akan dikoreksi adalah laporan Laba rugi komersial yang dibuatoleh perusahaan berdasarkan standar akuntansi yang berlaku, untuk dilakukan Rekonsiliasi fiskal berdasarkanperaturan perpajakan yang berlaku saat ini. Dimana penelitian akan dilakukan pada Laporan laba rugi komersial yang dibuat oleh $\mathrm{PT}$ XYZ berdasarkan standar akuntansi. Berikut ini yang akan menjadi fokus penelitian untuk analisis Rekonsiliasi Fiskal dalam rangka perhitungan pajak penghasilan badan pada laporan laba-rugi periode 1 Januari - 31 Desember 2019 adalah sebagai berikut:

\begin{tabular}{|c|c|}
\hline Nama Wajib Pajak & $: \underline{\text { PT XYZ }}$ \\
\hline Jenis Usaha & $\begin{array}{l}\text { : Perdagangan } \\
\text { besar }\end{array}$ \\
\hline \multicolumn{2}{|l|}{$\begin{array}{l}\text { Laporan Rugi } \\
\text { Tahun 2019 }\end{array}$} \\
\hline I.Penjualan Bersih & Rp25.000.000.000 \\
\hline II. Harga pokok Penjualan & $\underline{\mathrm{Rp} 11.000 .000 .000}$ \\
\hline $\begin{array}{l}\text { Laba Bruto/ penghasilan } \\
\text { Bruto }\end{array}$ & Rp11.000.000.000 \\
\hline \multicolumn{2}{|l|}{$\begin{array}{l}\text { III Biaya/ pengurang } \\
\text { penghasilan bruto }\end{array}$} \\
\hline $\begin{array}{l}1 \text { Biaya Gaji dan } \\
\text { tunjangan karyawan }\end{array}$ & Rp 1.000.000.000 \\
\hline $\begin{array}{l}\text { 2. Biaya umum dan Adm } \\
\text { kantor }\end{array}$ & Rp800.000.000 \\
\hline 3. Biaya perjalanan Dinas & Rp160.000.000 \\
\hline $\begin{array}{l}\text { 4. Biaya bunga pinjaman } \\
\text { Bank }\end{array}$ & Rp100.000.000 \\
\hline $\begin{array}{l}\text { 5.Biaya penelitian dan } \\
\text { pengembangan }\end{array}$ & Rp300.000.000 \\
\hline $\begin{array}{l}\text { 6. Biaya sewa mesin ke } \\
\text { PT XYZ }\end{array}$ & Rp200.000.000 \\
\hline $\begin{array}{l}\text { 7. Biaya pembelian bensin } \\
\text { mobil kantor }\end{array}$ & Rp70.000.000 \\
\hline 8. Biaya Cadangan piutang & Rp100.000.000 \\
\hline $\begin{array}{l}\text { 9.Biaya Penghapusan } \\
\text { cadangan Piutang }\end{array}$ & Rp100.000.000 \\
\hline $\begin{array}{l}\text { 10.Biaya reperasi } \\
\text { kendaraan kantor }\end{array}$ & Rp200.000.000 \\
\hline $\begin{array}{l}\text { 11.Biaya air, telepon dan } \\
\text { listrik kantor }\end{array}$ & Rp200.000.000 \\
\hline $\begin{array}{ll}\text { 12.Biaya } & \text { asuransi } \\
\text { perusahaan } & \end{array}$ & Rp100.000.000 \\
\hline $\begin{array}{l}\text { 13.Biaya iklan } \\
\text { promosi }\end{array}$ & Rp50.000.000 \\
\hline
\end{tabular}

\begin{tabular}{|l|r|}
\hline 14. Biaya jamu tamu & $\mathrm{Rp} 150.000 .000$ \\
\hline 15. Biaya sumbangan & $\mathrm{Rp} 200.000 .000$ \\
\hline $\begin{array}{l}\text { 16 Biaya penyusutan } \\
\text { gudang, pabrik, kantor }\end{array}$ & $\mathrm{Rp} 100.000 .000$ \\
\hline $\begin{array}{l}\text { 17. Biaya PBB kantor dan } \\
\text { pabrik }\end{array}$ & $\mathrm{Rp} 150.000 .000$ \\
\hline $\begin{array}{l}\text { 18. Biaya PPH 25 tahun } \\
\text { 2019 }\end{array}$ & $\mathrm{Rp} 200.000 .000$ \\
\hline 19. Biaya keamanan & $\mathrm{Rp} 20.000 .000$ \\
\hline 20.Biaya makan karyawan & $\mathrm{Rp} 15.000 .000$ \\
\hline 21. Biaya pakaian direksi & $\mathrm{Rp} 18.000 .000$ \\
\hline $\begin{array}{l}\text { 22.Premi } \\
\text { kesehatan }\end{array}$ & $\mathrm{Rp} 50.000 .000$ \\
\hline $\begin{array}{l}\text { 23. Sanksi pajak, denda, } \\
\text { bunga }\end{array}$ & $\mathrm{Rp} 20.000 .000$ \\
\hline $\begin{array}{l}\text { 24.Total biaya/ pengurang } \\
\text { penghasilan bruto }\end{array}$ & $\mathrm{Rp} 4.303 .000 .000$ \\
\hline $\begin{array}{l}\text { 25.Laba } \\
\text { penghasilan bruto }\end{array}$ & $\mathrm{Rp} 9.697 .000 .000$ \\
\hline $\begin{array}{l}\text { 26.Penghasilan bunga } \\
\text { deposito }\end{array}$ & $\mathrm{Rp} 20.000 .000$ \\
\hline $\begin{array}{l}\text { 27.Penghasilan } \\
\text { sumbangan }\end{array}$ & $\mathrm{Rp} 500.000 .000$ \\
\hline $\begin{array}{l}\text { 28. Penghasilan PPH } \\
\text { penjualan tanah }\end{array}$ & $\mathrm{Rp} 100.000 .000$ \\
\hline $\begin{array}{l}\text { 29. Penghasilan transaksi } \\
\text { sahama BEJ }\end{array}$ & $\mathrm{Rp} 1.000 .000 .000$ \\
\hline 30. Jumlah penghasilan \\
\hline $\begin{array}{l}\text { 31. Jumlah laba bersih / } \\
\text { penghasilan neto }\end{array}$ & $\mathrm{Rp} 1.620 .000 .000$ \\
\hline
\end{tabular}

Sumber Laporan Keuangan PT XYZ 2019

Data-data tambahan pembukuan perusahaan:

1. Dalam biaya gaji terdapat biaya fasilitas menempati fasilitas apartement yang dipakai oleh Direktur dibayar perusahaan, dengan biaya sewa selama setahun Rp 100.000.000,-

2. Dalam biaya perjalanan dinas yang tidak ada bukti pendukung sebesar Rp 5.000.000,-

3. Biaya penelitian dan pengembangan di Singapura Rp 100.000.000,-

4. Dalam pembelian bensin mobil kantor yang tidak bukti pembayarannnya $\mathrm{Rp}$ 5.000.000,-

5. Biaya penghapusan piutang pajak tak tertagh telah memenuhi syarat syarat UU Pajak 
6. Dalam biaya reparasi kendaraan terselip perbaikan kendaraan pribadi pegawai Rp 25.000.000,-

7. Dalam biaya air,telp dan listrik tetapi terdapat biaya pemasangan telephone untuk rumah direktur dibebankan ke perusahaan sebesar Rp 5.000.000,-

8. Biaya jamuan tamu, dimana bukti bukti yang dapat diterima secara pajak sebesar $80 \%$

9. Biaya berobat pegawai diberikan diberikan dalam berupa tunjangan setiap bulan berupa kas Rp 40.000.000,- dan dalam bentuk fasilitas datang langsung kerumah sakit yang ditunjuk perusahaan sebesar Rp 10.000.000,-

10. Perhitungan penyusutan sudah menggambarkan keadaan yang sebenaranya dan metode garis lurus

11. Kompensasi kerugian tahun $2018 \mathrm{Rp}$ 1.315.000.000,-

12. PPH Pasal 22 dengan nilai import $\mathrm{Rp}$ 1.000.000.000,- perusahaan import memakai angka API dipungut Bea Cukai

\section{Perhitungan penghasilan kena pajak:}

Penghasilan objek pajak Rp 25.000.000.000

Harga pokok penjualan Rp 11.000.000.000

Penghasilan bruto $\quad$ Rp 14.000.000.000

Pengurang peng bruto $\quad \mathrm{Rp} \quad 3.685 .000 .000$

Penghasilan neto pajak Rp 10.315.000.000

Kompensasi kerugian tahun sebelumnya

Rp 1.315.000.000

Penghasilan kena Pajak Rp 9.000.000.000

PPH terutang tahun 2019

25\% X Rp 9.000.000.000 Rp 2.250.000.000

Kredit Pajak dan setor sendiri:

$\begin{array}{llc}\text { PPH pasal 22 } & \text { Rp } & 25.000 .000 \\ \text { PPH pasal 25 } & \text { Rp } & 200.000 .000 \\ & \text { Rp } & 225.000 .000(-)\end{array}$

PPH kurang bayar/ PPH pasal 29 Rp

2.025.000.000

PPH Pasal 22 Impor 2,5\% X 1.000.000.000

Rp $\quad 25.000 .000$ 


\section{Laporan Rekonsiliasi Fiskal Pajak}

Tahun 2019

\begin{tabular}{|c|c|c|c|c|c|c|}
\hline \multirow{2}{*}{$\begin{array}{ll}\mathrm{NO} \\
1 \\
\end{array}$} & \multirow{2}{*}{$\begin{array}{l}\text { POS PERKIRAAN } \\
\text { Penjualan bersih } \\
\end{array}$} & \multicolumn{2}{|c|}{$\begin{array}{l}\text { L/R Komersial } \\
\text { (Rp) }\end{array}$} & \multirow[t]{2}{*}{$\begin{array}{l}\text { KOREKSI PAJAK } \\
(\mathrm{Rp})\end{array}$} & \multicolumn{2}{|c|}{$\begin{array}{l}\text { L/R PAJAK } \\
\text { (Rp) }\end{array}$} \\
\hline & & & 25.0000 .0000 .000 & & & 25.000 .000 .000 \\
\hline II & HPP & & & & & \\
\hline & Persediaan awal & 10.000 .000 .000 & & & 10.000 .000 .000 & \\
\hline & Pembelian & 6.000 .000 .000 & & & 6.000 .000 .000 & \\
\hline & Barang tersedia dijual & 16.000 .000 .000 & & & 16.000 .000 .000 & \\
\hline & Persediaan akhir & 5.000 .000 .000 & & & 5.000 .000 .000 & \\
\hline & Harga pokok penjualan & 11.000 .000 .000 & & & 11.000 .000 .000 & \\
\hline & Laba bruto & & 14.000 .000 .000 & & & 14.000 .000 .000 \\
\hline III & Biaya pengurang penghasilan bruto & & & & & \\
\hline & Biaya gaji dan tunjangan pegawai & 1.000 .000 .000 & & $(100.000 .000)$ & 900.000 .000 & \\
\hline & Biaya admintrasi umum kantor & 800.000 .000 & & & 800.000 .000 & \\
\hline & Biaya perjalanan dinas & 160.000 .000 & & $(5.000 .000)$ & 155.000 .000 & \\
\hline & Biaya bunga pinjaman bank & 100.000 .000 & & & 100.000 .000 & \\
\hline & Biaya penelitian dan pengembangan & 300.000 .000 & & $(1000.000 .000)$ & 200.000 .000 & \\
\hline & Biaya sewa pada PT ABC & 200.000 .000 & & & 200.000 .000 & \\
\hline & Biaya pembelian bensin mobil kantor & 70.000 .000 & & $(5.000 .000)$ & 65.000 .000 & \\
\hline & Biaya cadangan piutang & 100.000 .000 & & $(100.000 .000)$ & 0 & \\
\hline & Biaya penghapusan cadangan piutang & 100.000 .000 & & & 100.000 .000 & \\
\hline & Biaya reparasi kendaraan kantor & & & & & \\
\hline
\end{tabular}




\begin{tabular}{|c|c|c|c|c|c|}
\hline & 200.000 .000 & & $(25.000 .000)$ & 175.000 .000 & \\
\hline Biaya listrik,telp,air kantor & 200.000 .000 & & $(5.000 .000)$ & 195.000 .000 & \\
\hline Biaya asuransi perusahaan & 100.000 .000 & & & 100.000 .000 & \\
\hline Biaya iklan dan promosi & 50.000 .000 & & & 50.000 .000 & \\
\hline Biaya jamu tamu & 150.000 .000 & & $(30.000 .000)$ & 120.000 .000 & \\
\hline Biaya sumbangan bencana alam & 200.000 .000 & & & 200.000 .000 & \\
\hline $\begin{array}{l}\text { Biaya penyusutan gudang,pabrik,dan } \\
\text { kantor }\end{array}$ & 100.000 .000 & & & 100.000 .000 & \\
\hline Biaya PBB & 150.000 .000 & & & 150.000 .000 & \\
\hline Biaya PPH pasal 25 & 200.000 .000 & & $(200.000 .000)$ & 0 & \\
\hline Biaya iuran kemananan & 20.000 .000 & & & 20.000 .000 & \\
\hline Biaya makan karyawan & 15.000 .000 & & & 15.000 .000 & \\
\hline Biaya pakaian kerja direksi & 18.000 .000 & & $(18.000 .000)$ & 0 & \\
\hline Biaya berobat pegawai & 50.000 .000 & & $(10.000 .000)$ & 40.000 .000 & \\
\hline Sanksi pajak & 20.000 .000 & & $(20.000 .000)$ & 0 & \\
\hline Total biaya pengurang penghasilan bruto & 4.303.000.000 & & 618.000 .000 & 3.685 .000 .000 & \\
\hline Laba bruto /penghasilan bruto & & 9.697 .000 .000 & & & 10.315 .000 .000 \\
\hline Penghasilan bunga deposito & & 20.000 .000 & $(20.000 .000)$ & & 0 \\
\hline Penghasilan sumbangan & & 500.000 .000 & $(500.000 .000)$ & & 0 \\
\hline Penghasilan PPH final jual tanah & & & & & \\
\hline
\end{tabular}




\begin{tabular}{|l|l|r|r|r|r|r|}
\hline & & & 100.000 .000 & $(100.000 .000)$ & & \\
\hline & Penghasilan dari transaksi saham BEJ & & 1000.000 .000 & 1.000 .000 .000 & & \\
\hline & Jumalah penghasilan lain lain & & 1.620 .000 .000 & $(1.620 .000 .000)$ & & \\
\hline & Laba bersih / penghasilan neto & & 11.317 .000 .000 & & & 0 \\
\hline & & & & & & 10.315 .000 .000 \\
\hline
\end{tabular}

Sumber Data diolah 2020 


\section{KESIMPULAN}

Berdasarkan hasil analisa perhtungan Rekonsilasi Fiskal terhada Laporan Keuangan PT XYZ , makadapat ditarik kesimpulan sebagai berikut.

Perhitngan rekonsilasi fiskal terhadap Lapora keuangan PT XYZ sangat perlu dilakukan karena dapat membantu dalam rangka perhitungan pajakpenghasilan badan sehingga Perusahaan PT XYZ Nusa dapat melakukan pembayaran pajak penghasilan badan sesuai dengan peraturan perpajakan yang berlaku. PT XYZ telah membuat perhitungan Laporan Rekonsiliasi dalam rangka perhitungan PajakPenghasilan Badan dari laporan Laba/Rugi fiskal untuk 31 Desember 2019 dengan Laba bersih sebelum pajak berdasarkanperhitungan dalam laporan laba-rugi komersial 31 Desember yang diperoleh PT sebesar Rp 11.317.000.000,-. Kemudian setelah dilakukan perhitungan rekonsilasi fiskal atas laporan laba rugikomersial, laba bersih sebelum pajak menurut fiskal yang dimiliki PT XYZ adalah sebesar Rp. 10.315.000.000,- Perhitungan pajak penghasilan badan PT XYZ telah dilakukan sesuai tarif pajak yangberlaku berdasarkan peredaran bruto perusahaan dan dengan menggunakan laba bersih sebelum pajakmenurut fiskal.

Adapun saran-saran dari penelitian ini adalah sebagai berikut:

Setiap Wajib Pajak Badan (perusahaan) sebelum mengisi SPT PPH Pasal 25 diwajibkan membuat perhtingan Rekonsiliasi Fiskal ini agar sesuai dengan perhitungan Pajak sesuai Undang Undang Pajak yang belaku saat ini.

keterbatasan waktu dalam penelitian ini dapat dijadikan sebagai acuan peneliti selanjutnya dalam memberikan informasi serta menambahkan teori, data yang lebih konkrit, dan detail yang berhubungan rekonsiliasi fiskal serta mengenai analisa penerapan perhitungan rekonsiliasi fiskal terhadap laporan keuangan komersial pada perusahaan berdasarkan peraturan dari Direktorat Jendral Pajak dan sistem akutansi yang berlaku di Indonesia.

\section{KETERBATASA}

Karena keterbatasan waktu, serta data data yang tidak semua diberikan oleh PT XYZ maka dalam penelitian ini hanya membatasi analisa perhitungan rekonsiliasi fiskal terhadap laopran komersial PT XYZ

\section{DAFTAR PUSTAKA}

Analisis terhadapkoreksi fiskal pajak penghasilan pada PT Bitung MinaUtama di kota Bitung Ryan C.C Languju, Jantje J. Tinangon, Inggriani Elim Vol 2, No 3 (2014),

https://ejournal.unsrat.ac.id/ind ex.php/emba/article/view/5782

Analisis Rekonsiliasi Fiskal atas laba rugi dalam penentuan pajak penghasilan ( PPh ) terutang Empud Syarifuddin, Toni Andrianto, Miftahudin Mifftahudin Vol 1, No 1 (2014),http://jurnal.stiekesatua n.ac.id/index.php/joma/article/ view/795

Analisis penerapan laporan rekonsiliasi fiskal terhadap laporan keuangan komersial pada PT Citra Karya Sejati, (Irene Maria dan Siti Khairani, 2011), STIE MDP, http://eprints.mdp.ac.id/722/

Edy Supriyanto, Akutansi Perpajakan, Graha Ilmu. Jakarta 2016

Laporan Keuangan Perusahaan PT XYZ 2019. Jakarta

Siti Resmi, Perpajakan, Penerbit Salemba Empat Jakarta 2018.

Soemitro, Rohmat, dalam( Mardiasmo) Perpajakan, edisi 
revisi, Penerbit BPFE Yogyakarta 2019

Pohan, Chairil Anwar. 2016 Manajemen Perpajakan Strategi Perencanaan Pajak dan Bisnis. Gramedia. Jakarta

Undang Undang Nomor 16 tahun 2009 tentang perubahan tentang
Ketentuan Umum dan Tata cara Perpajakan

Undang Undang Nomor 36 Tahun 2008 tentang Pajak Penghasilan 